\title{
Erratum to: Creating New Links Between Agriculture and Food Aid: New Perspectives from France
}

\author{
Matthieu Duboys de Labarre, Aurélie Carimentrand, Chantal Crenn, \\ Anne-Hélène Delavigne, Karen Montagne, Cristina Parvu, \\ Dominique Paturel, Frédéric Précigout and Isabelle Techoueyres
}

\section{Erratum to: \\ Chapter 7 in: M. Caraher and J. Coveney (eds.), Food Poverty and Insecurity: International Food Inequalities, Food Policy, DOI 10.1007/978-3-319-23859-3_7}

The sequence of the chapter author names was published incorrectly. The correct sequence should be: Matthieu Duboys de Labarre, Aurélie Carimentrand, Chantal Crenn, Anne-Hélène Delavigne, Karen Montagne, Cristina Parvu, Dominique Paturel, Frédéric Précigout and Isabelle Techoueyres

The online version of the original chapters can be found under DOI 10.1007/978-3-319-23859-3_7

M. Duboys de Labarre $(\bowtie) \cdot$ A. Carimentrand · C. Crenn · A.-H. Delavigne $\cdot$ K. Montagne ·

C. Parvu · D. Paturel · F. Précigout · I. Techoueyres

CESAER UMR 1041 INRA-Agrosup Dijon, Dijon, France

e-mail: matthieu.de-labarre@dijon.inra.fr 